\title{
Enhanced production of parthenocarpic cucumbers pollinated with stingless bees and Africanized honey bees in greenhouses
}

\section{Incremento da produção de pepino partenocárpico com abelhas sem ferrão e Africanizadas em casas de vegetação}

\author{
Daniel Nicodemo ${ }^{1 *}$; Euclides Braga Malheiros ${ }^{2}$; \\ David De Jong ${ }^{3}$; Regina Helena Nogueira Couto ${ }^{4}$
}

\begin{abstract}
Crops have different levels of dependence on pollinators; this holds true even for cultivars of the same species, as in the case of cucumber (Cucumis sativus). The aim of this research was to assess the attractiveness of flowers of three Japanese parthenocarpic cucumber cultivars and evaluate the importance of Africanized bees (Apis mellifera), and the Brazilian native stingless bees, Jatai (Tetragonisca angustula) and Iraí (Nannotrigona testaceicornis) on fruit production. Several parameters, including frequency of bee visits to flowers as well as duration of nectar collection and fruit set were examined; additionally, fruit weight, length and diameter were evaluated. Three greenhouses located in Ribeirão Preto, SP, were used for planting three cucumber cultivars (Hokushin, Yoshinari and Soudai). The female flowers were more attractive than male flowers; however, Jataí bees were not observed visiting the flowers. The Africanized and the Iraí bees collected only nectar, with a visitation peak between 10 and $12 \mathrm{~h}$. Visits to female flowers had a longer duration than visits to male flower visits in all three cultivars. Africanized bee colonies declined due to loss of bees while in the greenhouse; the native stingless bee colonies did not suffer these losses. When bees were excluded, fruit set was $78 \%$; however, when bees had access to the flowers, fruit set was significantly (19.2\%) higher. Fruit size and weight did not differ with and without bees. This demonstrates that even in parthenocarpic cucumber cultivars, which do not require pollination in order to from fruits, fruit production is significantly increased by bee pollination.
\end{abstract}

Key words: Apis mellifera, Nannotrigona testaceicornis, Tetragonisca angustula, fruit set, parthenocarpic cucumber

\section{Resumo}

As culturas agrícolas apresentam diferentes níveis de dependência por polinizadores e essa expressão variada ocorre inclusive entre cultivares de uma espécie, como no caso das plantas de pepino (Cucumis sativus). O objetivo desse trabalho foi avaliar a atratividade das flores de pepino Japonês de três cultivares e a importância das abelhas Africanizadas (Apis mellifera), as abelhas brasileiras sem ferrão, Jataí (Tetragonisca angustula) e Iraí (Nannotrigona testaceicornis), na produção de frutos . Foram

\footnotetext{
1 Prof. Dr. do Curso de Zootecnia, Câmpus de Dracena, Universidade Estadual Paulista "Júlio de Mesquita Filho", UNESP, Dracena, SP, Brasil. E-mail: nicodemo@dracena.unesp.br

2 Prof. Dr. do Dept ${ }^{\circ}$ de Ciências Exatas, Faculdade de Ciências Agrárias e Veterinárias, UNESP, Jaboticabal, SP, Brasil. E-mail: euclides@fcav.unesp.br

3 Prof. Dr. do Dept $^{\circ}$ de Genética, Faculdade de Medicina de Ribeirão Preto, Universidade de São Paulo, USP, Ribeirão Preto, SP, Brasil. E-mail: ddjong@fmrp.usp.br

$4 \operatorname{Prof}^{\mathrm{a}} \mathrm{Dr}^{\mathrm{a}}$ do Dept ${ }^{\mathrm{o}}$ de Zootecnia, Faculdade de Ciências Agrárias e Veterinárias, UNESP, Jaboticabal, SP, Brasil. E-mail: reginahelena85@yahoo.com.br

* Author for correspondence
} 
analisados vários parâmetros como a frequência de visitas de abelhas às flores, o tempo de visita utilizado para a coleta de néctar e a taxa de frutificação, considerando-se o peso, o comprimento e diâmetro dos pepinos obtidos. Foram utilizadas três casas de vegetação em Ribeirão Preto, SP, para o cultivo de três cultivares de pepino (Hokushin, Yoshinari e Soudai). Verificou-se que as flores femininas são mais atrativas que as masculinas e que as abelhas Jataí não visitaram as flores. As abelhas Africanizadas e Iraí coletaram apenas néctar, com pico de visitação entre $10 \mathrm{~h}$ e $12 \mathrm{~h}$. Visita às flores femininas tiveram uma maior duração do que as visitas às flores masculinas nas três cultivares. As abelhas Africanizadas tiveram suas colônias diminuídas devido à perda de abelhas enquanto na casa de vegetação; as abelhas nativas não sofreram perdas. Com a retirada das abelhas, a frutificação foi de $78 \%$, porém, quando as abelhas tiveram acesso às flores, a frutificação foi significativamente maior $(19,2 \%)$. O tamanho e o peso dos frutos não diferiu em relação à presença das abelhas. Isto demonstra que mesmo em cultivares de pepino partenocárpico, que não necessita de polinização para formar frutos, a produção de frutos e significativamente maior pela polinização por abelhas.

Palavras-chave: Apis mellifera, Nannotrigona testaceicornis, Tetragonisca angustula, frutificação, pepino partenocápico

\section{Introduction}

Like most of the Cucurbitaceae, the production of cucumber (Cucumis sativus) increases when insects pollinate the crop. When there are not enough bees in the area to efficiently transfer pollen to the flower stigmas, it becomes necessary to introduce hives to attain good yields (JONES; ROSA, 1928; ALEX, 1957; FILGUEIRA, 1981; NOGUEIRA-COUTO; CALMONA, 1993; ROSELINO; SANTOS; BEGO, 2010).

In a study conducted in Canada, using a monoecious variety of cucumber called Reider, it was concluded that if bees do not visit the flowers, fruit is not produced. One visit by Apis mellifera to female flowers allowed for fruit set, albeit at low levels. A larger number of visits and a longer duration per visit led to higher fruit set and larger fruit size (GINGRAS; GINGRAS; OLIVEIRA, 1999). Santos, Roselino and Bego (2008), evaluated the effect of introduction of Scaptotrigona aff. depilis and Nannotrigona testaceicornis (Hymenoptera: Meliponini) bees in greenhouses and concluded that the production of Caipira cucumbers was higher when stingless bees were present.

Most Japanese cucumber cultivars are parthenocarpic, and they have been widely marketed in many countries, with seeds derived mainly from Europe and Asia. The parthenocarpy trait makes crop production possible in greenhouses, in places where there is a shortage of pollinators and in scenarios where there is inadequate synchronization between male and female flowers (CARDOSO; SILVA, 2003). Some environmental factors, such as short days and low nighttime temperatures, stimulate the formation of parthenocarpic cucumber fruits (FERRI, 1979). It is generally believed by growers that it is not advantageous to place bee colonies in greenhouses with parthenocarpic cucumber varieties.

Cucumber plants should be cultivated in regions with temperatures above $20^{\circ} \mathrm{C}$ because lower temperatures result in less absorption of water and nutrients by the plant. Therefore, the use of greenhouses for cucumber production is advantageous, making this the most widely grown crop in greenhouses worldwide (ROBINSON; DECKER-WALTERS, 1999).

Bee pollination in greenhouses is difficult, as it requires adaptation and management of bees indoors. Colonies are adapted to nature, and bees seek food and other products that are up to a few kilometers from the hive (COUTO; COUTO, 2006; CRUZ; CAMPOS, 2009). Nevertheless, various crops in greenhouses are pollinated with native and Africanized bees (VELTHIUS, 2002; MALAGOLI-BRAGA; KLEINERT, 2007, SANTOS; ROSELINO; BEGO, 2008; ROSELINO, SANTOS; BEGO, 2010). 
We assessed the attractiveness of the flowers of three cultivars of Japanese cucumber and evaluated the pollination efficiency of Africanized honey bees and the Brazilian native bees Iraí (N. testaceicornis) and Jataí (Tetragonisca angustula), taking into account the frequency of bee visits to flowers, the time that bees remain on the flower, and fruit production, which was evaluated by measuring fruit number, weight, length and diameter.

\section{Material and Methods}

The test was made with three parthenocarpic cultivars of a Japanese cucumber (C. sativus), namely Hokushin, Yoshinari and Soudai. Seeds of the cultivars were sown in cultivation trays containing substrate and maintained in a greenhouse for 20 days. After this initial growth period, the seedlings were transplanted to greenhouses located in Ribeirão Preto, SP, Brazil, which has a subtropical climate.

One cucumber cultivar was planted in each of three greenhouses that measured $8 \times 13 \times 1.8 \mathrm{~m}$ (w x 1 $\mathrm{x} \mathrm{h}$ ). All of the greenhouses were covered with a film of low-density polyethylene and protected on the sides with an anti-aphid screen. For each cucumber cultivar, 144 seedlings were planted with $0.50-\mathrm{m}$ spacing between plants and $1.0 \mathrm{~m}$ between rows. The plants were fertilized by fertirrigation, based on soil analysis and recommendations of Technical Bulletin 100-IAC (RAIJ et al., 1997).

In the pollination trials, Africanized honey bee (A. mellifera), Jataí hives and Iraí hives were used; these were introduced at the beginning of flowering. Throughout the bloom period in each greenhouse, one hive of a single species was introduced weekly. Using a rotating system, the same species were introduced into each greenhouse twice in six weeks. At the end of each week, the hives were removed from the greenhouses and were kept outside the greenhouses for seven days. During this time, other colonies of the same species participated in the rotation.
Attractiveness of male and female flowers was evaluated by observing the frequency of bee visitations. The percentage of insects that visited male and female flowers was determined throughout the day over a four-day time period.

The frequency of insect visitations during the day was estimated through visual observation that covered the entire greenhouse. The number of bees was counted during a 10-minute period, every hour from the beginning until the end of flower visitation, twice a week (replicates = days). A completely randomized $3 \times 3$ factorial split plot design (three cucumber cultivars and three bee species) was used; the sub-plots were the hours.

The duration of nectar collection was measured using a stopwatch, at 9:00 and 15:00 for three days. We used a randomized block design (block = day) and a $3 \times 2 \times 2$ factorial scheme (three cultivars, two hours and two types of flowers).

To determine the effect of bee visitation on fruit production, 10 female flowers were randomly chosen from each cultivar prior to anthesis and marked; this was repeated six times for each bee species (three repetitions for each of two colonies). Of these, half were covered with nylon bags, thus preventing bee visitation, while half remained uncovered, thus allowing bees to visit freely. Each week, during the time that the bee colonies were in the greenhouses, we obtained the percentage fruit set along with the weight, length and diameter in each greenhouse. The fruit diameter was measured with a caliper positioned at the midpoint of its length. The fruits were harvested when they reached commercial size.

For statistical analyses, the data were submitted to analysis of variance. For multiple comparisons, the Tukey test at a significance level of 5\% was used. The analyses were performed with SAS (1993). 


\section{Results and Discussion}

The Jataí bees did not visit the cucumber flowers, and during the time that they were in the greenhouses, they fed only on what was inside of their hives, as the only other food sources available were pollen and nectar from cucumber flowers. However, the Iraí bees visited the flowers of all of the cultivars; the total number of visits was $43.5 \%$ lower than the visits by Africanized bees (Figure 1). It is possible that visitation of native bees would have been greater if they had been trained, as suggested by Roselino, Santos and Bego (2010). However, this practice demands considerable manpower and other resources that discourage its adoption.

Figure 1. Frequency of visits by Africanized and Iraís bees collecting nectar from male and female flowers throughout the day in three cucumber cultivars (Hokushin, Yoshinari and Soudai) cultivated in greenhouses.
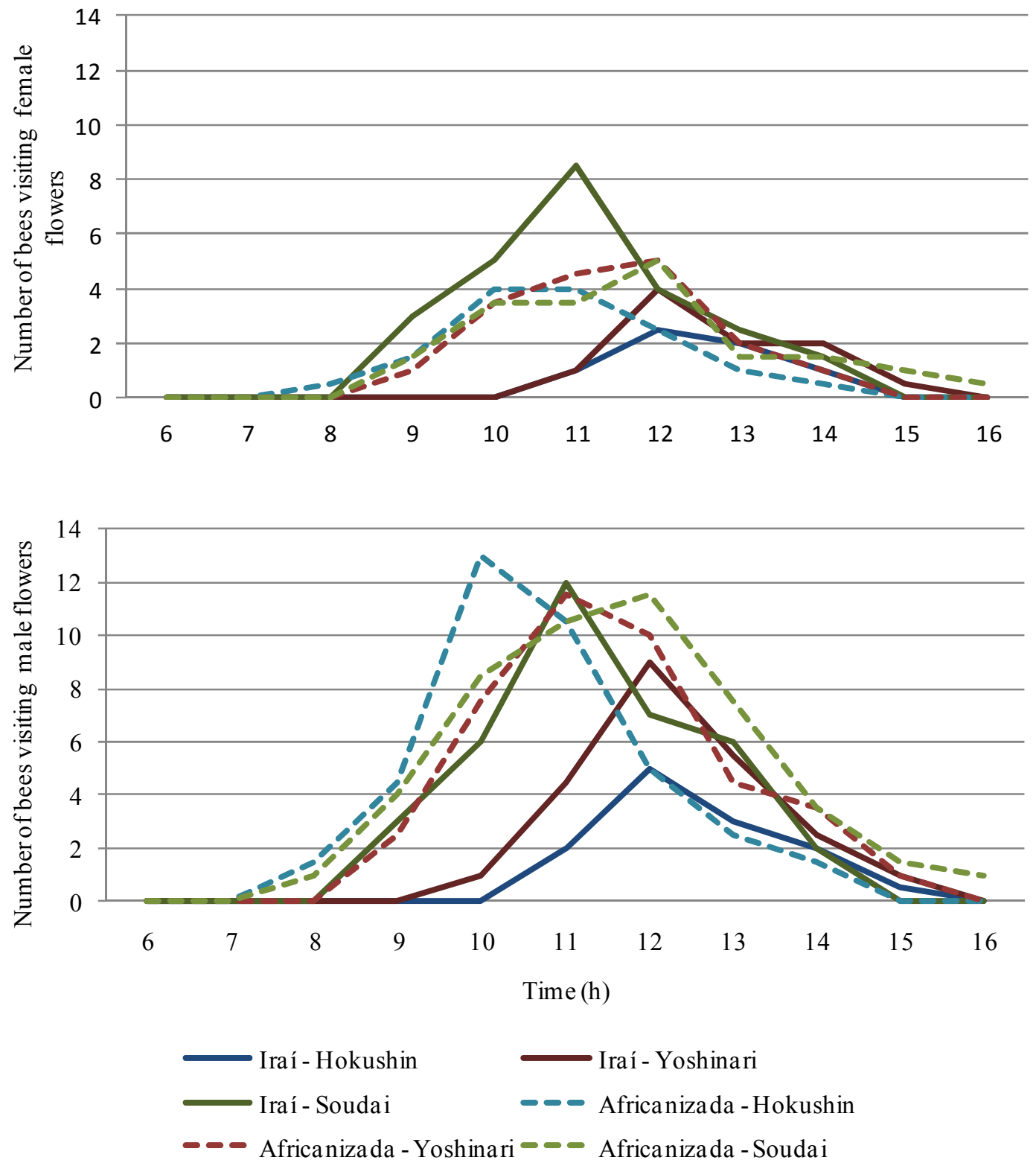

Source: Elaboration of the authors. 
The Africanized and Iraí bees did not collect pollen from any of the three cucumber cultivars. The probable low pollen production of these cultivars, or other factors not assessed, such as adherence of pollen to the stamen, may have inhibited the bees' interest in pollen collection. In some crops, the pollen grains are attached to the anthers, and it is only released when bees that perform buzz pollination visit the flowers (FREE, 1993; NUNESSILVA; HRNCIR; IMPERATRIZ-FONSECA, 2010), though this is not the case for cucumbers.

Considering that these cultivars produce 1.9 times more male than female flowers on average (NICODEMO et al., 2012), and that male flowers were visited only 1.2 times more than female flowers, it appears that the female flowers were more attractive. This could be because female flowers produce nectar in greater quantity, and their nectar has a higher sugar concentration compared to male flowers, especially in cucurbits (FREE, 1993; NICODEMO et al., 2007).

The Africanized and Iraí bees began to visit flowers at approximately 7:00, and visits became more frequent between 10:00 and 12:00. After 16:00, there were no more visits to the flowers. In a study of Caipira variety cucumber pollination in greenhouses, Santos, Roselino and Bego (2008), found that the bee species introduced into the greenhouses, $S$. aff. depilis and $N$. testaceicornis, visited the flowers between 8:00 and 16:00, with a visitation peak between 10:00 and 13:00. This visiting time to cucumber flowers was similar to that which we observed, even though different cucumber varieties were utilized.

The Africanized bees visited the cucumber flowers throughout the experimental period, even in the early days of hive introduction; however, a large number of bees were observed to fly at the screen, trying to exit the greenhouse. Many did not return to the hive, and at the end of the weekly periods, the colony populations had decreased such that the maintaining the hive in the greenhouse or transfer to another greenhouse was not possible. In the rotation system, the hives had to be systematically replaced. Honey bees are efficient at finding floral resources although they have difficulty adapting to indoor conditions (COUTO; COUTO, 2006). The native bees did not fly at the aphid screen and the colony populations remained stable during the time that they were in the greenhouses.

The mean duration of the visits of Africanized bees were 6.78, 5.48 and $5.89 \mathrm{~s}$ at 9:00, and 4.97, 4.30 and $4.38 \mathrm{~s}$ at 15:00 for flowers of the cultivars Hokushin, Yoshinari and Soudai, respectively (Table 1). There was an interaction between the cultivar and the type of flower. The duration of visits to the male flowers was longest $(p<0.05)$ for Hokushin, followed by Yoshinari and Soudai, which exhibited similar values. The duration of visits to female flowers did not differ significantly $(p>0.20)$ among the cultivars. However, in all cultivars, the visits were longer at female flowers.

An analysis of the duration of visitation of Iraí bees revealed an interaction between all the factors studied (Table 2). For the interaction "cultivar $x$ hour" at 9:00, the longest visits occurred on Yoshinari and Hokushin flowers, lasting 22.0 and 20.4 s, respectively. Shorter visits occurred on Soudai flowers (18.1 s). Among the cultivars, there was no difference in the duration of afternoon visits. In all cases, visits in the morning lasted longer than those that occurred during the afternoon. 
Table 1. Time of nectar collection performed by Africanized bees on the flowers of three Japanese cucumber cultivars (Hokushin, Yoshinari and Soudai) cultivated in greenhouses.

\begin{tabular}{cccc}
\hline \multirow{2}{*}{ Statistics } & \multicolumn{2}{c}{ Duration of nectar collection } \\
\cline { 2 - 4 } & cultivar x time & $9: 00$ & $15: 00$ \\
\hline \multirow{5}{*}{ Averages } & Hokushin & 6.78 & 4.97 \\
& Yoshinari & 5.48 & 4.30 \\
& Soudai & 5.89 & 4.38 \\
\cline { 2 - 4 } & cultivar x type of flower & Male & Female \\
\cline { 2 - 4 } & Hokushin & $5.52 \mathrm{Ab}^{1}$ & $6.23 \mathrm{Aa}$ \\
& Yoshinari & $4.13 \mathrm{Bb}$ & $5.65 \mathrm{Aa}$ \\
& Soudai & $3.93 \mathrm{Bb}$ & $6.34 \mathrm{Aa}$ \\
\cline { 2 - 4 } & type of flower x time & $9: 00$ & $15: 00$ \\
\cline { 2 - 4 } & Male & 5.18 & 3.88 \\
& Female & 6.93 & 5.22 \\
\hline
\end{tabular}

${ }^{1}$ For each interaction, averages that are followed by the same letters (uppercase letters in columns and lowercase letters in rows) are not significantly different $(p>0.05)$ based on the Tukey test.

Source: Elaboration of the authors.

Table 2. Duration of nectar collection performed by Iraí bees on flowers of three Japanese cucumber cultivars (Hokushin, Yoshinari and Soudai) cultivated in greenhouses.

\begin{tabular}{clcc}
\hline \multirow{2}{*}{ Statistics } & \multicolumn{1}{c}{ Interaction } & \multicolumn{2}{c}{ Duration of nectar collection } \\
\cline { 2 - 4 } & \multicolumn{1}{c}{ cultivar x time } & $9: 00$ & $15: 00$ \\
\hline & Hokushin & $20.44 \mathrm{Aa}^{2}$ & $15.59 \mathrm{Ab}$ \\
& Yoshinari & $22.00 \mathrm{Aa}$ & $16.42 \mathrm{Ab}$ \\
& Soudai & $18.13 \mathrm{Ba}$ & $15.78 \mathrm{Ab}$ \\
\cline { 2 - 4 } & \multicolumn{1}{c}{ cultivar x type of flower } & Male & Female \\
\cline { 2 - 4 } Averages & Hokushin & $16.28 \mathrm{Bb}$ & $19.76 \mathrm{Aa}$ \\
& Yoshinari & $19.48 \mathrm{Aa}$ & $18.94 \mathrm{Aa}$ \\
& Soudai & $15.46 \mathrm{Bb}$ & $18.45 \mathrm{Aa}$ \\
\cline { 2 - 4 } & \multicolumn{1}{c}{ type of flower x time } & $9: 00$ & $15: 00$ \\
\cline { 2 - 4 } & Male & $18.66 \mathrm{Ba}$ & $15.48 \mathrm{Ab}$ \\
& Female & \multicolumn{3}{c}{$16.38 \mathrm{Ab}$} \\
\hline $\mathrm{CV}(\%)$ & & & 10.8 \\
\hline
\end{tabular}

${ }^{2}$ For each interaction, averages followed by the same letters (uppercase letters in the columns and lowercase letters in rows) are not significantly different $(p>0.05)$ based on the Tukey test.

Source: Elaboration of the authors.

For the interaction "cultivar x type of flower", we found that on male flowers, the Iraí bee visits were longer on flowers of the cultivar Yoshinari. There was no significant difference in visit duration between female flowers of the different cultivars; however, visits to female flowers were longer than visits to male flowers. For the interaction "type of flower x time", we found that at 9:00, the visits were longer at the female flowers; however, at 15:00, there was no difference between the two types of flowers. We observed that the visits to female flowers lasted longer in the morning. We found that the nectar had a higher concentration of sugar in the afternoon; however, it is likely that the greatest amount of nectar is available in the morning, which explains the shorter visits compared to at 15:00 (NICODEMO et al., 2012). 
The fruit set was higher when the flowers were available for visitation by bees (Table 3). All flowers from the cultivar Hokushin that were marked and open to bee visitation resulted in fruits. For the cultivar Yoshinari, the fruit set was higher when the flowers were available for visitation by Africanized bees. In the cultivar Soudai, visits from both Africanized and Iraí bees led to total efficiency in cucumber fruit set.

Table 3. Fruit set (\%) in three Japanese cucumber cultivars (Hokushin, Yoshinari and Soudai) cultivated in greenhouses, taking into account the introduced bee species (Africanized, Iraí and Jataí) and the availability of flowers for bee visitation.

\begin{tabular}{|c|c|c|c|c|c|c|c|c|c|}
\hline & & \multicolumn{6}{|c|}{ Cucumber cultivar } & \multirow{2}{*}{\multicolumn{2}{|c|}{ Averages }} \\
\hline & & \multicolumn{2}{|c|}{ Hokushin } & \multicolumn{2}{|c|}{ Yoshinari } & \multicolumn{2}{|c|}{ Soudai } & & \\
\hline \multicolumn{2}{|c|}{ Availability of flowers } & open & closed & open & closed & open & closed & open & closed \\
\hline \multirow{3}{*}{ Bee } & Africanized & 100,0 & 80,0 & 100,0 & 60,0 & 100,0 & 80,0 & 100,0 & 73,0 \\
\hline & Iraí & 100,0 & 80,0 & 80,0 & 80,0 & 100 & 80,0 & 93,0 & 80,0 \\
\hline & Jataí & 100,0 & 80,0 & 80,0 & 80,0 & 80,0 & 80,0 & 87,0 & 80,0 \\
\hline \multicolumn{2}{|c|}{ Averages } & 100,0 & 80,0 & 87,0 & 73,0 & 93,0 & 80,0 & 93,0 & 78,0 \\
\hline
\end{tabular}

Source: Elaboration of the authors.

None of the three bee species collected pollen from flowers of any of the three cultivars; however, we found that the bees made contact with the stamens while collecting nectar. As the average fruit set for all cultivars was higher when the flowers were open to visitation by bees, we can assume that during collection of nectar, the workers had their bodies impregnated with pollen grains that were transported to other flowers, including female flowers, where the bees were also searching for nectar.

Among the three bee species, the most efficient pollinator species was the Africanized bee, which gave a fruit set of $100 \%$, followed by Iraí, which gave a fruit set of 93\%. Gingras, Gingras and Oliveira (1999), concluded that, for the Reider variety, one visit from $A$. mellifera on one female flower could result in the formation of a fruit. In an assessment of the importance of bees for Aodai cucumber production, Nogueira-Couto and Calmona (1993) concluded that honey bees facilitate cucumber fruit set due to their visits to the flowers, thus promoting pollination. Africanized bees can efficiently pollinate several species of the genus Cucurbita (FREE, 1993; NICODEMO et al., 2009, VIDAL et al., 2010).
Since the three evaluated cultivars are parthenocarpic, fruit production was not severely compromised when bees did not visit the flowers. However, the introduction of beehives into the greenhouses contributed to a $19.2 \%$ increase in the overall average fruit set of these Japanese cucumbers (Table 3). When we consider only the flowers open to visits by Africanized and Iraí bees, given that Jataí was not observed visiting the cucumber flowers, the increase in production was $26 \%$.

The average weight of fruits of the cultivar Soudai was greater $(154.8 \mathrm{~g} ; p<0.05)$ than those of the cultivar Hokushin, which weighed an average of $146.6 \mathrm{~g}$ (Table 4). The fruits of the cultivar Yoshinari weighed $151.0 \mathrm{~g}$ on average. The diameters of the fruits of three cultivars were similar $(p>0.05)$, with an average of $2.2 \mathrm{~cm}$. Regarding the effect of the bees, we found that the Iraí bees contributed to a significant increase in fruit diameter, in comparison with fruit produced in the greenhouse with Jataí bees; there was also a significant increase in fruit length, compared to those produced in greenhouses with Africanized or Jataí bees (Table 4). 
Table 4. Weight, length and diameter of established fruits on the flowers of three cucumber cultivars (Hokushin, Yoshinari and Soudai) cultivated in greenhouses with or without bee visitation (Iraí, Jataí or Africanized).

\begin{tabular}{|c|c|c|c|c|c|}
\hline & Statisti & & Weight (g) & Length $(\mathrm{cm})$ & Diameter $(\mathrm{cm})$ \\
\hline \multirow{8}{*}{ Averages } & \multirow{3}{*}{ Cultivar } & Hokushin & $146.58 b^{3}$ & $20.08 \mathrm{~b}$ & $2.12 \mathrm{a}$ \\
\hline & & Yoshinari & $151.04 \mathrm{ab}$ & $20.92 \mathrm{~b}$ & $2.08 \mathrm{a}$ \\
\hline & & Soudai & $154.77 \mathrm{a}$ & $21.87 \mathrm{a}$ & $2.24 \mathrm{a}$ \\
\hline & \multirow{3}{*}{ Bee } & Irai & $153.28 \mathrm{a}$ & $21.40 \mathrm{a}$ & $2.29 \mathrm{a}$ \\
\hline & & Jataí & $147.20 \mathrm{a}$ & $20.23 \mathrm{~b}$ & $2.00 \mathrm{~b}$ \\
\hline & & Africanized & $151.85 \mathrm{a}$ & $21.23 \mathrm{~b}$ & $2.14 \mathrm{ab}$ \\
\hline & \multirow{2}{*}{ Flowers } & with visits & 151.60 & 20.94 & 2.16 \\
\hline & & without visits & 149.79 & 20.97 & 2.13 \\
\hline CV (\%) & & & 7.03 & 4.00 & 14.29 \\
\hline
\end{tabular}

${ }^{3}$ For each comparison (cultivars, bees, availability of flowers to bee visitation), averages followed by the same letters within each evaluated factor (weight, length and diameter) are not significantly different $(p>0.05)$ based on the Tukey test.

Source: Elaboration of the authors.

When we examined the factor fruit length, we found an interaction between the factors "cultivar $\mathrm{x}$ visitation" and "species x visitation". Among the fruits that originated from flowers that were open to bee visitation, the fruit length was greater in the Soudai and Yoshinari cultivars. The fruits of Soudai were significantly longer than those of the other cultivars when the fruits originated from flowers that were not visited by bees (Table 4). However, when the flowers were visited by bees, all cultivars produced fruit of similar length.

We found that bee visits did not improve parthenocarpic cucumber crop quality, in terms of fruit weight, length and diameter. However, bee pollination benefited crop yield by significantly increasing the number of fruits.

\section{Conclusions}

Bee visits to cucumber were longer in the morning, and the Iraí bees remained on the flowers for a longer time compared to the Africanized bees; however, the Africanized bees visited more flowers per day. The Jataí bees were not observed visiting the cucumber flowers.

Placing colonies of Africanized or Iraí bees in the greenhouse promotes increased production of parthenocarpic cucumber cultivars $26 \%$. In all three cultivars that were analyzed, this increase resulted from the formation of a larger number of fruit, with no effect on weight or format of the cucumbers.

\section{References}

ALEX, A. M. Honeybees aid pollination of cucumbers and cantaloupes. Gleanings in Bee Culture, Medina, v. 85, n. 7, p. 389-400, 1957.

CARDOSO, A. I. I.; SILVA, N. Avaliação de híbridos de pepino tipo japonês sob ambiente protegido em duas épocas de cultivo. Horticultura Brasileira, Brasília, v. 21, n. 2, p. 171-176, 2003.

COUTO, R. H. N.; COUTO, L. A. Apicultura: manejo e produtos. Jaboticabal: FUNEP, 2006. 193 p.

CRUZ, D. O.; CAMPOS, L. A. O. Polinização por abelhas em cultivos protegidos. Revista Brasileira de Agrociência, Pelotas, v. 15, n. 1-4, p. 5-10, 2009.

FERRI, M. G. Fisiologia vegetal. São Paulo: Editora da Universidade de São Paulo, 1979. 350 p.

FILGUEIRA, F. A. R. Manual de olericultura: cultura e comercialização de hortaliças. São Paulo: Agronômica Ceres, 1981.338 p.

FREE, J. B. Insect pollination of crops. London: Academic Press, 1993. 544 p.

GINGRAS, D.; GINGRAS, J.; OLIVEIRA, D. Visits of honeybees (Hymenoptera: Apidae) and their effects on cucumber yield in the field. Journal of Economic Entomology, Lanham, v. 92, n. 2, p. 435-438, 1999. 
JONES, H. A.; ROSA, J. T. Truck crop plants. New York: McGraw-Hill, 1928. 109 p.

MALAGOLI-BRAGA, K. S.; KLEINERT, A. M. P. Como o comportamento das abelhas na flor do morangueiro (Fragaria $\mathrm{x}$ ananassa Dushesne) influencia a formação dos frutos? Bioscience Journal, Uberlândia, v. 23, n. 1, p. 76-81, 2007.

NICODEMO, D.; COUTO, R. H. N.; MALHEIROS, E. B.; DE JONG, D. Biologia floral em moranga (Cucurbita maxima Duch. var. "Exposição"). Acta Scientiarum. Agronomy, Maringá, v. 29, p. 611-616, 2007. Suplemento.

NICODEMO, D.; COUTO, R. H. N.; MALHEIROS, E. B.; DEJONG, D. Honey bee as an effective pollinating agent of pumpkin. Scientia Agricola, Piracicaba, v. 66, n. 4, p. 476-480, 2009.

NICODEMO, D.; MALHEIROS, E. B.; DEJONG, D.; COUTO, R. H. N. Biologia floral de pepino (Cucumis sativus L.) tipo Japonês cultivado em estufa. Cientifica, Jaboticabal, v. 40, n. 1, p. 35-40, 2012.

NOGUEIRA-COUTO, R. H. N.; CALMONA, R. C. Polinização entomófila em pepino (Cucumis sativus L. var. Aodai melhorada). Naturalia, São Paulo, v. 18, p. 77-82, 1993.

NUNES-SILVA, P.; HRNCIR, M.; IMPERATRIZFONSECA, V. L. A polinização por vibração. Oecologia Australis, Rio de Janeiro, v. 14, n. 1, p. 140-151, 2010.

RAIJ, B. van; CANTERELLA, H.; QUAGGIO, J. A.; FURLANI, A. M. C. Recomendações de adubação e calagem para o Estado de São Paulo. Campinas: IAC, 1997. $285 \mathrm{p}$.
ROBINSON, R. W.; DECKER-WALTERS, D. S. Cucurbits. Cambridge: CAB International, 1999. 226 p.

ROSElinO, A. C.; SANTOS, S. A. B.; BEGO, L. R. Qualidade dos frutos de pimentão (Capsicum annuum L.) a partir de flores polinizadas por abelhas sem ferrão (Melipona quadrifasciata anthidioides Lepeletier 1836 e Melipona scutellaris Latreille 1811) sob cultivo protegido. Revista Brasileira de Biociências, Porto Alegre, v. 8, n. 2, p. 154-158, 2010.

SANTOS, S. A. B.; ROSElinO, A. C.; BeGO, L. C. Pollination of Cucumber, Cucumis sativus L. (Cucurbitales: Cucurbitaceae), by the Stingless Bees Scaptotrigona aff. depilis Moure and Nannotrigona testaceicornis Lepeletier (Hymenoptera: Meliponini) in Greenhouses. Neotropical Entomology, Londrina, v. 37, n. 5, p. 506-512, 2008.

SAS INSTITUTE - Statistical analysis systems. Cary: SAS Institute Inc., 1993. 890 p.

VELTHIUS, H. H. W. The historical background of the domestication of the Bumblebee, Bombus terrestris and its introduction in agriculture. In: KEVAN, P. G.; IMPERATRIZ-FONSECA, V. L. (Ed.). Pollinating bees: the conservation link between agriculture and nature. Brasília: Ministério do Meio Ambiente, 2002. p. 177184.

VIDAL, M. G.; DEJONG, D.; WIEN, H. C.; MORSE, R. A. Pollination and fruit set in pumpkin (Cucurbita pepo) by honey bees. Revista Brasileira de Botânica, São Paulo, v. 33, n. 2, p. 107-113, 2010. 
